UDC 372.64.20

МРНТИ 14.25.05, 15.25.09

\author{
G.A. Rizakhodjayeva ${ }^{1}$, I.S. Abdulamit ${ }^{1}$ \\ Khoja Akhmet Yassawi International Kazakh-Turkish University, Republic of Kazakhstan \\ *(e-mail: gulnara_rizahodja@mail.ru)
}

\title{
Current perspectives on pronunciation skill development
}

\begin{abstract}
Annotation
Main problem: the article discusses the importance of modern methods used in the development of pronunciation skills in teaching English in Kazakh schools. Currently, in their practice, teachers are guided by four main areas: listening, speaking, reading, and writing. However, if we partially distinguish these skills, there are many auxiliary skills: pronunciation, spelling, grammar, vocabulary, punctuation... and much more. Here, the most important of these skills is the pronunciation skill, so the research work included providing the most effective modern methods aimed at developing students ' pronunciation skills, applying them on the basis of practice, and differentiating the result.

Purpose: to determine the importance of pronunciation in a student's ability to speak a foreign language fluently and suggest ways to develop it using the 'Ben Franklin' exercise.

Methods: descriptive, systematization and analytical methods were used in the course of the study.

Results and their significance: the authors of the article identified the important role of pronunciation skills in the development of students 'fluency in English in the modern updated educational process of the country and proposed the Ben Franklin exercise, aimed at developing students' pronunciation skills in the process of teaching English. Within the framework of world education, English teachers are able to generalize the importance of a new type of technology for the development of any language competence of a student in the acquisition of a foreign language by a student. After all, changes in the progressive development of society lead to the introduction of new ideas and modern traditions in the content of Education.
\end{abstract}

\section{Keywords: pronunciation, skill development, fluency, Ben Franklin, effective methods}

\section{Introduction}

Learning English and speaking English are becoming more and more popular among young people, but it is difficult for them to learn the grammatical structure, correct speech and pronunciation of words, express their thoughts without errors, and speak fluently. When conveying a thought in English, it is necessary to differentiate the words that the student remembers and add them to the entire speech to convey their thought. In order to memorize words, you need to systematize them in relation to something specific. In their practice, teachers are guided by four main areas: listening, speaking, reading, and writing. However, if we partially differentiate these skills, there are also many auxiliary skills that we can use: pronunciation, spelling, grammar, vocabulary, punctuation... and much more.

Currently, when teaching English among English teachers, the main focus is on the rules of grammatical structure, working with the dictionary, and not much attention is paid to the correct pronunciation of words. According to Kelly, vocabulary and grammar have been studied longer than pronunciation, so teaching grammar and vocabulary is better understood by many Language teachers than teaching pronunciation [1].

Fluency in learning a foreign language by students and speaking in the correct structure has become a controversial issue among scientists. In the context of questions about whether it is important to pay attention to the grammatical structure or whether it is important for the student to speak fluently, there are several opinions. Some scientists argue that when a language learner learns a foreign language, it is necessary to learn a rule, formula, and grammatical structure of the language, while some scientists interpret it as the ability to understand the meaning of the language and use the language [2]. In this case, we decided to show the theoretical justification, possible practical development of the competence of language attributes, which develops in the periodic process of teaching English on the basis of information technologies, identifying and considering ways to develop the importance of correct speech skills of a student in the development of fluency competence in the process of teaching English.

\section{Materials and methods}

Young researcher K. R. Narzullaev in his research shows that knowledge of a foreign language is the knowledge and application of all the rules, skills, sequence of sentence formation in order for a student to speak the language they are learning clearly. He said that it is possible to determine the level of language proficiency based on the student's ability to speak fluently.

Exercises and various world studies for the parallel development of the student's pronunciation and writing skills require the organization of various games and tasks for the development of the student's ability to speak fluently. Some students may be able to speak good English and write well in writing without errors, but they are shy about public speaking. On the other hand, some students are fluent in the language, but cannot speak 
fluently. The main problem of Foreign Language teachers is that they prefer to work with grammatical errors rather than with students ' pronunciation skills. They believe that grammar is the first thing you need to know when learning English [3]. In his work it is said that teaching a second language, when a child learns to speak a new language from a very young age, he learns not grammar, but to speak first by looking at the objects around him, nature, and the movements of his mother and other people. And speaking about the fact that he learned grammar after going to school, he wrote that we can develop students' clear correct speech by introducing them not to grammar at first, but to phenomena, images that are happening around them, and through developing various sound/song, video/listening skills.

Ebsworth believes that the importance of free speech is to be understood by the second person. When a language learner speaks with the correct use of language structure, grammar, it may be difficult for the second person in the process of communication to understand the lexical meaning, syntactic structure, or pronunciation of a word. Therefore, the ability to speak fluently in a foreign language and express thoughts in a semantic structure is very important in the process of communication. That is, the target language indicates that you need to develop at the level of your ability to speak.

When learning a foreign language, students ' fluency skills are effective in communication, but it is important to pay attention to grammatical errors. Although a student is taught conversational skills in a foreign language at an early age, the level of fluency in communication will be low if their grammar is not taken seriously [4].

Developing students' skills in grammatical structure, correct expression of phrases, correct pronunciation of words, the ability to express their thoughts without errors, and fluency in teaching foreign language can be the bright way to our students on speaking fluently and accuracy without any mistakes.

English is a language that differs in pronunciation from other foreign languages. The most important thing in learning a language is the correct pronunciation of a word. It is necessary to know the laws of sound spelling, understand the difference between a letter and a sound, and have general phonetic literacy.

R.Krishnasamy says: "Despite having a good grasp of vocabulary and the grammatical rules of the English language, speakers would be unintelligible if they had poor pronunciation" [5]. If you speak a foreign language with a strong foreign accent, people may have difficulty understanding you, even if you use the grammar of the language well and have an extensive knowledge of the vocabulary. The better your pronunciation, the easier it will be for others to understand you and for you to understand them.

Pronunciation plays an important role in learning a foreign language. Students' good knowledge of correct pronunciation skills in communication contributes to their fluency. Low pronunciation skills alienate the student from the general language environment. The student cannot actively participate in the exchange of opinions if he does not have confidence in himself. It has a negative impact on the assessment of the speaker's authority and abilities. Methods of communication for proper pronunciation development will be promoted. In the study of A. P. Gilakjani, features of pronunciation, factors influencing assimilation, are considered. These skills are combined with the curriculum, and various methods and directions of pronunciation skills are presented for foreign language learners [6].

In his research, Pardede emphasized the pedagogical importance of planned learning, especially the importance of proper language pronunciation. Correct pronunciation is an important part of language communication, and if a student and a teacher work together on pronunciation, the student will show good results. He also pointed out that it is important for the teacher to take into account that the student is part of the learning process, and the system of listening should be organized in parallel, so that the teacher can easily learn the pronunciation of a foreign language, setting a goal for himself to achieve the good result.

According to Pardede, as a "speech coach", a teacher should not test the student's pronunciation skills, but rather the teacher should give feedback to the student. In this way, students can expect a very good result if they are supported, teach correct pronunciation of words, and provide feedback on various tasks for developing fluency. He also reviews on guidelines for Effective Teaching Pronunciation in EFL Situation and Developing Speech Perception. Based on the results of his research work, he organized consultations and recommendations pronunciation training helps students develop their abilities. Here are these practical tips it is divided into three parts, which are parallel to the three stages of pronunciation training: meaningful and interesting way comparing pronunciation.

Teaching pronunciation in a meaningful and motivating way includes:

- Providing meaningful materials;

- Using songs, games, and tongue twisters;

- Assessing students' progress [7].

Creating a more relaxed and fun environment in the classroom has a positive impact on the learning process of EFL students. We know that many students love music, English Language teachers can do better to teach them their speaking skills. It is important to choose the most effective songs that meet the goals of the teacher and the needs of students. In addition, it is important to pronounce the words correctly when singing English songs. As studies show which conducted in Turkish schools on this issue has also been conducted from English teachers, and their answers have been summarized and analyzed by appropriate methods. In English language teaching departments, it is recommended to describe and encourage lessons based on songs. In 
addition, it is covered that several intelligence-oriented and especially productive skills-based training courses should be organized in Turkish public schools [8].

Uzbek researcher M. S. Ilkhomovna also suggested using interesting games, various songs to increase the activity of students in learning a foreign language. She proposed several methods aimed at fluency in English. For example, teaching students to sing in English, singing a song in a certain rhythm and with the correct accent. She also noted that motivating students also increases the student's interest in learning a foreign language. She said that it is also important for students to sing with sincere feelings, every rhythm helps them pronounce any word correctly.

In her research, she showed that various games also help with the correct pronunciation of words. For example, it shows a Mini-Bingo game as a good type of Game. Designed to increase the ability to correctly pronounce sounds and correctly pronounce intonation. The Tongue twister is also considered an effective method for special children who has a problem with pronunciation [9].

An important role in the development of pronunciation skills is played by such a variety of techniques and types of games that can distinguish the sound features of a foreign language. Speaking words with the correct accent, developing the ability to think in English, and fluently expressing thoughts can be a great step to success for every language learner.

In addition to language pronunciation, grammar also plays a special role in teaching a foreign language. The importance of grammatical learning should be at the forefront for the teacher. The student's desire to speak freely comes from self-confidence, and if the student wants to convey their thoughts in the past or future, he must make a sentence. Of course, the direct grammatical order of sentence formation is directly related to the rule. This is a relatively new phenomenon around the issue that has not yet been studied in the context of Saudi Arabia. Alghanmi, B., \& Shukri, N. in their research studies showed that although most studies focus on teaching grammar in general, more research is needed, especially regarding the understanding of teachers ' beliefs in grammar and grammar teaching, as well as their experience in the classroom . As a result, the level of language proficiency of students, their attitude to the language, their needs, teaching style, classroom environment and teacher development are the factors that influence the transformation of teachers' understanding of grammar and grammatical learning into practice. These findings will help expand the discussion about improving the quality of grammar teaching, especially in the EFL classroom in Saudi Arabia [10].

Obviously, teaching grammar and correct pronunciation of words is a serious problem for any teacher when developing a student's fluency in English when teaching a foreign language. Some experts believe that grammar and pronunciation are not important, and if a student can communicate using vocabulary, this is also an achievement for a teacher. Oyanedel, J.C. according to his research, he focused on his conflicting views among teachers and studied his beliefs about grammar teaching integrated into communicative learning in the context of the English language (EFL). First, a survey was developed and conducted to study the concepts of teachers (a) L2, (B) theories of grammatical learning and communicative learning, and (C) barriers to the implementation of communicative learning. The survey provided general support for grammar teaching through communicative methods. However, in these interviews, conflicting thoughts arose. As a result, pedagogical experience had a positive and negative impact on conflicting beliefs. In general, teachers ' beliefs about how to learn L2 have led to a different set of beliefs than those about how to learn L2 [11]. From this study, we can see that the effectiveness of teaching grammar is determined by a survey based on the views of teachers and practical work.

According to Marie Kretz, it is important to master pronunciation skills in teaching fluency in English. He used the method of jazz songs in his practice. Because Marie Kretz said that jazz songs are rich in rhythm and accent and do not tire the student and he said that he will involve teachers in the creative process. The study covered 8th grade students, and as a result of the study using the Jazz chant method, students ' pronunciation skills were significantly improved from very bad to good. According to the answers of the latest survey, the students conducted the lesson with great interest and fun [12].

Anisimova O. V. in her article considers four basic language skills: speaking, writing, reading and listening are different in different internet tools, which are taught through different internet networks. Currently, students are trying to master different dialects and variants of a foreign language through various media outlets, such as YouTube TV shows, blogs, and video blogs that teach the language. For this reason, the Internet is becoming a very rational tool for improving the correct pronunciation of English [13]. In this sense, YouTube plays a leading role as the dominant source of information and entertainment. But these methods are used very rarely in English lessons. Our research work, in addition to highlighting the importance of English pronunciation skills, provides an effective method. Therefore, we propose the Ben Franklin method, which is currently not widely used in English lessons.

\section{Results}

Our research work was carried out in the following areas:

- determining the student's level of pronunciation;

- monitoring the student's motivation and interest in learning based on the Ben Franklin method in a Foreign Language Lesson;

- determining the student's level of knowledge after the introduction of the Ben Franklin method in the lesson. The research work covered the 8th grade: students A /20/ and students B /20/. 20 students of Group A were considered as a control group and the plan was drawn up for the development of pronunciation skills for 4 
weeks. In the course of the study, first of all, by the platform 'Elsa speak' were determined the level of students of English proficiency pronunciation and use of grammar. As shown in Figure 1 the Elsa speak platform is one of the platforms that accurately determines students ' speech skills, including what letters they make mistakes in pronunciation, as well as accent, pronunciation, and clarity skills as a percentage. That's why we used this platform through a smartphone device to determine the level of pronunciation skills of research group A.
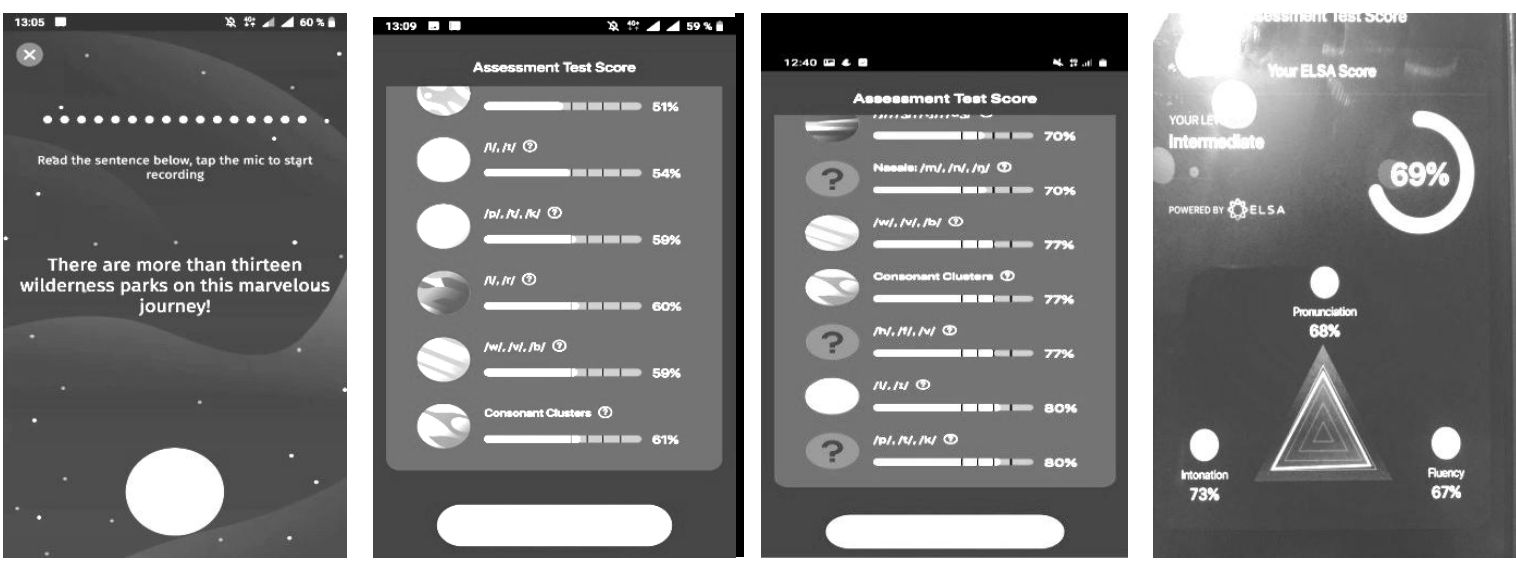

Figure 1 - Sample of the analysis results and the process of testing the pronunciation skills of the Elsa Speak platform.

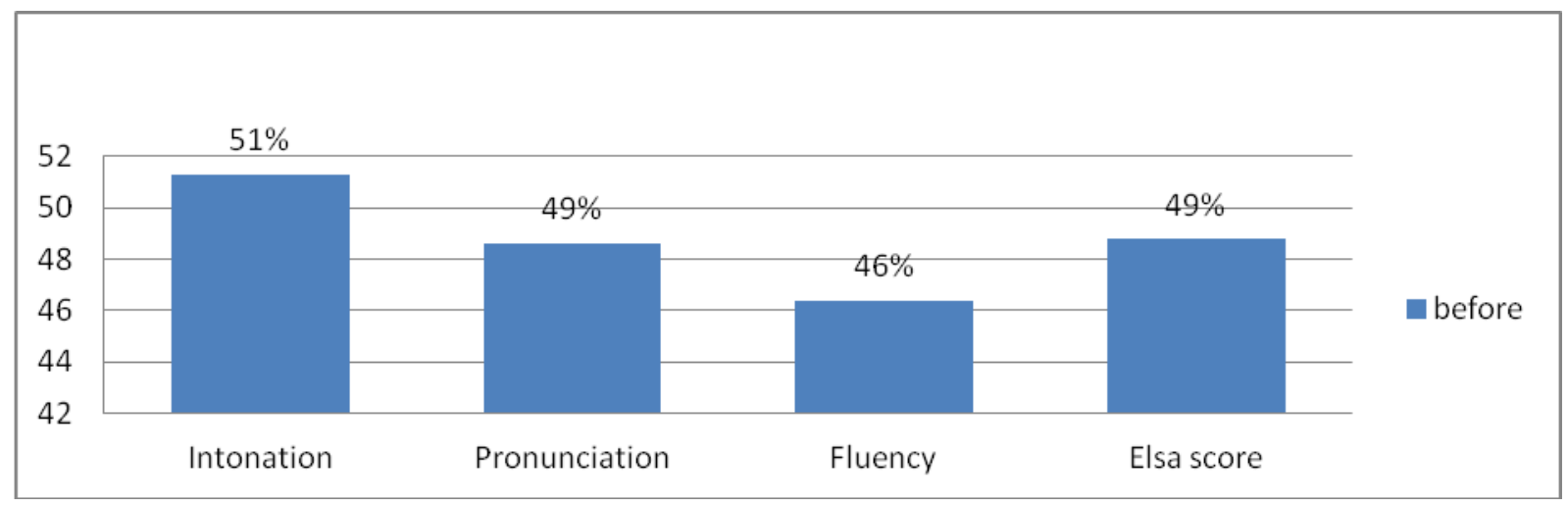

Figure 2 - Analysis of the results of the 'Elsa speak' on identification of the level of intonation, pronunciation and fluency

This diagram (Figure 2) shows that

- on average, the student's fluency showed $-46 \%$

- pronunciation skills - $49 \%$

- intonation - $51 \%$ and general Elsa score $-49 \%$

The level of this indicator indicates a low level for Kazakh classes, including for students of the 8th grade. In addition to determining the level of pronunciation of students, a survey was conducted to find out what exercises or additional English courses they independently participate in learning an additional foreign language outside of school, as well as what tasks they like to perform together with the English teacher at school and what practical methods are effective. As a result, different opinions were identified. Among the students, only 4 out of 20 students participate in an additional English language course outside of school and also identified 6 students who read books and listen to songs in English on an additional every day independently. Most of the students expressed a desire to listen to audio recordings, songs and watch movies with teacher in English lessons, rather than learn English independently. Taking into account these considerations, we decided to organize a lesson based on the 'Ben Franklin' exercises in order to develop students ' pronunciation skills in English. Because Ben Franklin exercises are used both in singing and watching movies and even in listening to or reading any text.

The Ben Franklin exercise was first introduced to English language learners by Rachel Smith author of the 'English Pronunciation book' from Philadelphia. In her You Tube channel there are a lot of different English pronunciation techniques, different exercises. However, we recommend this exercise as the most effective for school teachers.

Ben Franklin exercise is that a student, after listening to a sound recording several times, makes a sound recording of the same sound, word, or phrase. For example, 
I live in New York City, in Manhattan, currently in midtown. But I do move around a lot. I've been in New York for about five years, and I've already moved four times. One of the first things you should notice is how your voice goes up at the end of the word 'city', city, city. That's because of the comma here, and I'm not done, I'm going to keep going, I'm going to say more about that.

I live in New York City. [2x]

You should also notice how connected that first line is. I live in New York City. There are no breaks.

I live in New York City. [2x]

And we notice the ending consonant sound of 'live' links into the beginning of the next word, live in, vin, $v$-in, live in.

I live in New York City. [3x]

In Manhattan ...

In the development of general pronunciation skills, it is necessary to pay attention to the following issues:

- Rhythm and intonation

- Stressed word

- Vowels

- Consonants

- Diphthongs

In our research, these issues were the focus of teaching students pronunciation skills. Because the student's pronunciation skills and ability to speak fluently will develop well only with proper assimilation of these rules.

In the 1st week of the study, we carried out working on the textbook with students. When checking the initial level of pronunciation through the Elsa speak platform, students confused these sounds such as / $\mathrm{j} /(\mathrm{y}) ; / 3$ $/ \mathrm{d} 3 / ; / \mathrm{w} /, / \mathrm{v} /, / \mathrm{b} / ; / \mathrm{h} / / \mathrm{f} / / \mathrm{v} /$ in the course of research practice, it was important to repeat the spoken fragments of these sounds as much as possible, because there were many errors in the pronunciation of their sounds. The lesson of the 8th grade provided by the textbook English plus (Oxford University press), Unit 8, tasks from pages 92-94 was based Ben Franklin exercises. For example, in the course of listening to the dialogue which given in exercise 2, page 92, this method has a great effect on the correct pronunciation of these words: definitely, organize, donate, petition, campaign...etc. Language skills were developed on the correct reading of each letter and on the method of repetition, paying attention to the correct pronunciation of each sound.

During the 2nd week another our classes were held using various games, diagrams and tables on the basis of additional game 'Mono Bingo', 'Who is faster?'. It is very important to explain the grammatical structure on any topic. However, students find it difficult to memorize the rules of grammatical structure, verb forms, and grammar exercises are tedious for the student. Therefore, students can learn the grammatical structure through various songs. In this regard, the grammatical topic 'be going to and will' was taught through the song of Bruno Mars 'You can count on me' the song by Ben Franklin's training. By listening to the song and repeating their voices as a sound recording, they were able to master the rhythm of the song, the correct pronunciation of the words and the correct accent. The song was also very fun and gave the students a good mood, and students felt like a great singer by hearing their own voices from the audio recording. As a result, they learned grammar and a new vocabulary and learned to pronounce words correctly. Students began to develop correct pronunciation skills, paying attention to the sound of each letter.

During the 3rd week, work was carried out on the skills of listening and reading texts. Usually, a foreign language teacher speaks to students in a slow rhythm. This is because students need to understand every word of the teacher correctly. And when a student is given a listening task, they hear a word spoken in a very fast rhythm from an audio recording, and some students can not distinguish the words. In order to correct this flaw, The Ben Franklin exercise was used and for some words(cutlery, flour, dough, noodles) sound analysis was carried out and students got used to the correct pronunciation of new vocabularies.

In Week 4, students were shown excerpts from English films using the Ben Franklin exercise. In order to make it clear to the students, the film "Justice" was shown with subtitles. After listening to the passage over and over again, it was noticed that in the process of learning the sentence with subtitles students learned to pronounce the sentence quickly and clearly. When watching the film, attention was paid to the rhythm of each sentence, the accent of the words. Students with low abilities were analyzed not by sentences, but by the peculiarities of the sound of individual words.

When teaching English to speak, first of all, you need to know how each sound is pronounced and how it sounds. Analyzing the differences in the pronunciation of each letter and sound, it is necessary to teach the student articulation and assimilation rules. Determining the phonetic features of letters that are subject to assimilation changes is also very important in phonetic analysis. In order to teach students the pronunciation of words, every foreign language specialist must be fluent in the phonetics of their native language and the phonetics of the English language. This is because when teaching a foreign language, it will be much clearer to the student to compare the phonetic features of the native language with the phonetic features of the English language. For example, the letter ' $H$ ' and the sound feature in the Kazakh language the sound created by combining the letters ' $\mathrm{ng}$ ' in the English language is pronounced the same: the sound of ' $\mathrm{H}$ ' in the word 'aң' is similar to the sound of 'ng' in the word 'sing', the pronunciation of the letter ' $\mathrm{i}$ ' in the Kazakh language is 
similar to the pronunciation feature of ' $a$ '-a banana in the English language, which will greatly contribute to the development of the student's pronunciation skills.

\section{Discussion}

From our own experience, we determined the improvement of pronunciation skills of students through teaching them the sound characteristics of the English language and performing various tasks using the Ben Franklin exercise. In each lesson, students tried listen to carefully all recordings and also tried to record their voice without errors. The use of Ben Franklin's exercise in teaching English to students showed the following results:

- students could to read the words correctly;

- they got used to making their own recordings; phrases;

- their pronunciation skills improved significantly by repeating the correct pronunciation of words and

- they learned to identify the features of the sound of English letters;

- students' desire increased to speak like a native speaker. The ability to listen to audio recordings contributes to the development of the student's listening skills. The type of perception-related skills includes listening and reading skills. We say that reading is suitable for students to understand the text, but mastering this reading skill sets students many tasks. When reading, it is necessary to take into account the correct reading of each word, the specifics of its sound, accent, and other requirements. The exercise we conducted led the student to compare his shortcomings with the original by listening to himself whether he or she met these requirements correctly or not. And the main advantage is that the language learner can repeat the part of the recording that is not heard correctly. And the main disadvantage is that due to the acoustics of the classroom, students may not be able to hear the listening clearly.

- students learned to pay attention to intonation and accent when listening to music, movies, various videos. Through listening, students learn from the voice of their teacher to the voice of other people, speech style, speed, the ability to pronounce words correctly, and finally have the opportunity to speak fluently.

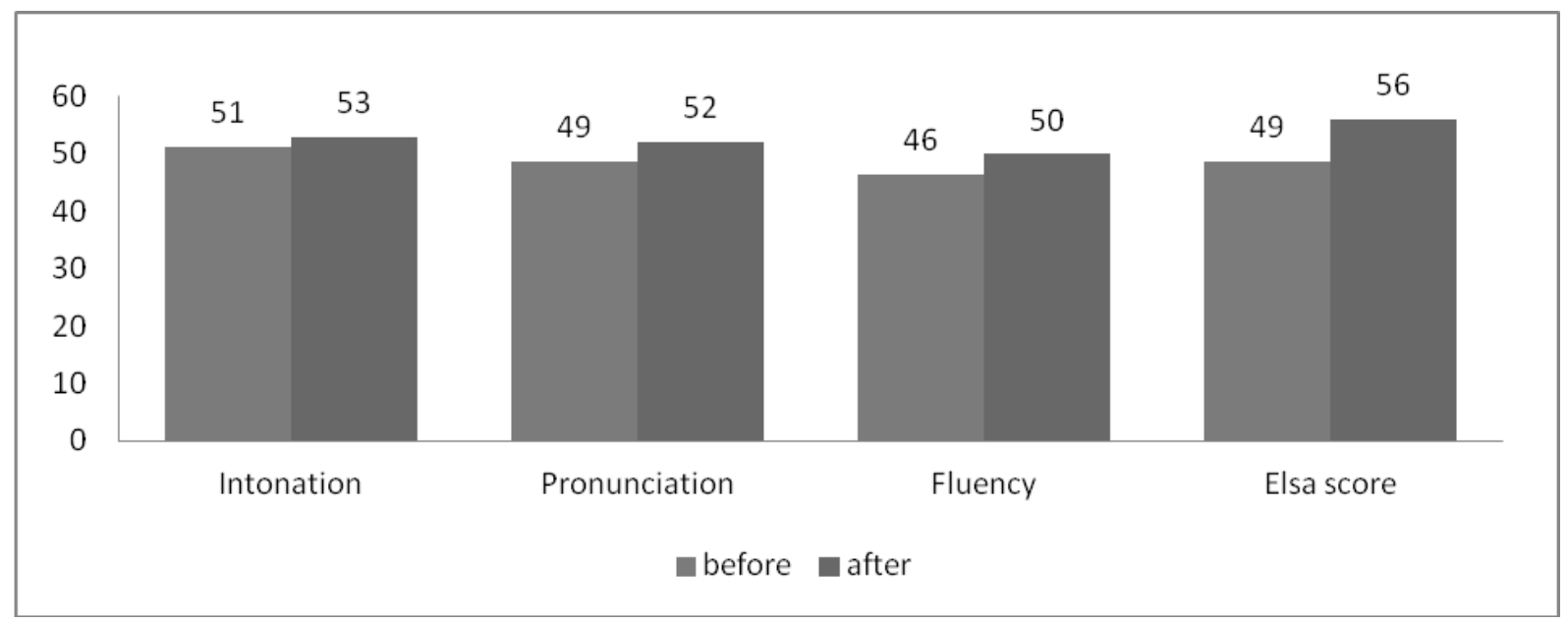

Figure 3 - Analysis of the results of identification of the level of intonation, pronunciation and fluency after training

This diagram (Figure 3) shows that

- on average, the student's fluency showed $-46 \%$ before training and $50 \%$ after training

- pronunciation skills $-49 \%$ before training and $52 \%$ after training

- intonation - $51 \%$ before training $53 \%$ after training and general Elsa score $-46 \%$ increased for $56 \%$ in 4weeks. These indicators indicate that Ben Franklin's training is an effective method of teaching English pronunciation skills. The student learns the correct pronunciation of sounds by listening, understands the meaning, and develops knowledge by mastering the content. Therefore, listening contributes to the student's understanding of spoken language. In our research, we presented the types of songs and movies to listen to. Song and film have different language features. At the same time, the speed of listening materials varies. Some words are not clearly to hear, their letters are changable and their intonations also vary depending on the context. When giving students a listening task, several principles were used: during the listening process, understanding the general content of the text, finding accurate information, understanding details and most importantly, paying attention to the correct pronunciation of words. On the basis of listening skills, students demonstrated the following achievements in performing various tasks on the Ben Franklin exercise:

- Students learned to apply the following applications and instructions in the classroom;

- can find the main idea, etc. delivers;

- notes differences between similar sounds; 
- learn to pay attention to keywords;

- learn to recognize the words of songs correctly;

General language lessons are focused on skills - first of all, it involves mastering the strategies necessary for life. Secondly, it facilitates the replenishment of Knowledge, offers optimal methods. It allows you to clearly evaluate the student's knowledge, provides a variety of classes. Prevents the uniformity of tasks, does not tire the student with a homogeneous task. Thus, it was found that the performance of the English language directly related to listening, reading skills through the Ben Franklin exercise in teaching texts, listening to songs and showing films played a major role in the development of the student's pronunciation competence.

\section{Conclusion}

In conclusion, we determined the role of pronunciation skills in the development of students' fluency in teaching English. Various aspects of the development of pronunciation skills were considered, and as a result of the study, we found that the Ben Franklin exercise developed the student's pronunciation competence, increased the desire to correctly pronounce words, speak fluently. The ability of a student to correctly pronounce words and pronounce them freely in English directly depends on the correct Organization of the updated learning system and the ability of qualified specialists to use rational methods. The student cannot clearly convey the meaning if he or she does not know how to pronounce the word correctly. Therefore, it is necessary to know that in the process of learning English, it is necessary to work on pronunciation skills. Since language is a means of communication, we believe that fluency in a foreign language is important for the bright future of our country in the exchange of modern foreign technologies and best practices in any field.

\section{REFERENCES}

1 Gerald, K., Harmer, J. Teaching pronunciation. How to teach pronunciation // Edinburgh Longman Educ. 2000. - pp. 11-28.

2 Antunez B. Implementing Reading First with English Language Learners // New York Dir. Lang. Educ. 2002. - № 15. - P. 1 .

3 Нарзуллаев К.Р., Наширова Ш.Б. Accuracy and fluency in language teaching // Молодой ученый, 2015. № 12. - pp. 939-941.

4 Shaban, A. Fluency activities in English for Palestine 8 Textbook from Teacher's and Student's view Points // Al-Azhar Univ.: Gaza, 2017. - pp. 231-240.

5 Krishnasamy, R., \& De Mello, G. Rethinking the teaching of pronunciation in the ESL classroom // English Teach. - 2017. - P. 14.

6 Gilakjani, A. A Study of factors Affecting EFL Learners' English pronunciation learning and the strategies for Instruction // International Journal of Humanities and Social Science. - 2012. - Vol. 2, № 3. - pp. 119-128.

7 Pardede, P. The role of pronunciation in a Foreign language program //Retrieved from https//parlindunganpardede.wordpress.com .

8 Atılır, Su-Bergil A. Relections of English language Teachers about the effect of using songs on pronunciation under a Creative Commons Attribution-NonCommercial-NoDerivatives (CC-BY-NC-ND) 4.0 license // Futuristic Implementations of Research in Education (FIRE). - 2020. - Vol. 1, № 2. - pp. 64-77.

9 Musurmonova, S.I. The role of pronunciation in Foreign language learning // Проблемы науки. - 2019. T. 5. - P. 41.

10 Alghanmi, B., Shukri, N. The Relationship between Teachers' Beliefs of grammar Instruction and classroom practices in the Saudi Context // English Lang. Teach. - 2016. - Vol. 9, № 7. - pp. 70-86.

11 Sato, M J. I think that is a better way to teach but: EFL teachers' conflicting beliefs about grammar teaching // System. - 2019. - № 84. - pp. 110-122.

12 Nurhayati, N., Nurhamdah, N. The effectiveness of Teaching pronunciation Through Jazz chants method // Inspiring: English Education Journal. - 2019. - pp. 83-96.

13 Anisimova, O., Bobodzhanova, L., Kolobova, K. M.I.S. Integration of Internet Tools to Enhance pronunciation Skills: effectiveness of educational content on YouTube / Lecture Notes in Networks and Systems: In Proceedings of the Conference "Integrating Engineering Education and Humanities for Global Intercultural Perspectives" - Springer, 2020. - Vol. 131. - pp. 199-211.

\section{Г.А. Ризаходжаева* ${ }^{1}$, И.С. Абдуламит ${ }^{1}$ \\ Қожа Ахмет Яссауи атындағы Халықаралық Қазақ-Түрік университеті, Қазақстан Республикасы}

\section{Айтылым дағдысын дамытудың заманауи перспективалары}

Мақалада қазақ мектептерінде ағылшын тілін оқытудың айтылым дағдысын дамытуда қолданылатын заманауи әдістердің маңыздылығы талқыланады. Қазіргі кезде мұғалімдер тәжірибелерінде төрт негізгі бағытты басшылыққа алады: тыңдалым, сөйленім, оқылым және жазылым. Алайда, осы дағдыларды ішінара ажырататын болсақ, көптеген көмекші дағдылар бар: айтылым, емле, грамматика, лексика, тыныс белгілері және т. б. Осы дағдылардың ішіндегі ең маңыздысы - айтылым 
дағдысы. Сондықтан зерттеу жұмысы студенттердің айтылым дағдыларын дамытуға бағытталған ең тиімді заманауи әдістерді ұсыну, практика негізінде қолдану және нәтижесін саралауды қамтыды.

Оқушының шет тілінде еркін сөйлеу қабілетінде айтылымның маңыздылығын анықтау және «Бен Франклин» жаттығуын қолдана отырып оның даму жолдарын ұсыну.

Зерттеу барысында сипаттамалық, жүйелеу және аналитикалық әдістер қолданылды.

Мақала авторлары еліміздің заманауи жаңартылған оқу үдерісінде оқушылардың ағылшын тілінде еркін сөйлеу қабілетін дамытуда айтылым дағдысының маңызды рөлін анықтайды және ағылшын тілін оқыту процесінде студенттердің айтылым дағдысын дамытуға бағытталған «Бен Франклин» жаттығуын ұсынады. Әлемдік білім беру аясында ағылшын тілі мұғалімдері үшін студенттің кез-келген тілдік құзіреттілігін дамытуда кешенді жаңа үлгідегі технологиялар оқушының шет тілін меңгеруі үшін маңызды деп қорытады. Себебі, қоғамның қарыштап дамуындағы өзгерістер жаңартылған білім беру негізінде білім беру мазмұнына жаңа идеялар мен заманауи дәстүр енгізуді алға қойып отыр.

Түйін сөздер: айтылым, дағдыларды дамыту, еркін сөйлеу, Бен-Франклин, тиімді әдістер.

\section{Г.А. Ризаходжаева**1, И.С. Абдуламит ${ }^{1}$}

Международный Казахско-Турецкий университет имени Ходжи Ахмеда Яссави, Республика Казахстан

\section{Современные перспективы развития навыков произношения}

В статье рассматривается значение современных методов, используемых в развитии навыков произношения при обучении английскому языку в казахских школах. В настоящее время в своей практике учителя руководствуются четырьмя основными направлениями: аудирование, говорение, чтение и письмо. Наряду с этим существует множество вспомогательных навыков: произношение, орфография, грамматика, лексика, пунктуация и др. Наиболее важным из этих навыков является произношение. Поэтому статья содержит анализ эффективных методов развития у студентов навыков произношения, применение на практике и дифференциацию результата.

Цель статьи - определить роль произношения в развитии говорения на иностранном языке и применение метода Бена Франклина.

В ходе исследования использовались описательный, системный и аналитический методы.

Авторы статьи определили роль произношения в развитии свободного владения английским языком у студентов и предложили упражнение Бена Франклина, направленное на развитие навыков произношения у студентов в процессе обучения английскому языку.

Ключевые слова: произношение, развитие навыков, беглость речи, Бен-Франклин, эффективные методы.

Date of receipt of the manuscript to the editor: 2021/05/03. 